\title{
ANALISIS KESULITAN BELAJAR SISWA PADA MATERI VIRUS DI KELAS X MIPA SMA NEGERI 1 RANTAU SELATAN TAHUN PEMBELAJARAN 2017/2018
}

\author{
Fatimah Dian Sari Harahap, M. Yusuf Nasution \\ Program Studi Pendidikan Biologi, FMIPA, Universitas Negeri Medan, Medan \\ Jl. Williem Iskandar Psr. V Medan Estate, Medan, Indonesia, 20221 \\ E-mail : fatimahdian25@gmail.com
}

\begin{abstract}
ABSTRAK
Penelitian ini bertujuan untuk mengetahui tingkat kesulitan belajar siswa pada materi Virus yang ditinjau dari aspek kognitif, indikator pembelajaran dan faktor penyebab. Metode yang digunakan adalah analisis tes penyebab kesulitan belajar siswa. Desain penelitian adalah deskriptif bersifat kuantitatif. Populasi dalam penelitian adalah seluruh siswa kelas X IPA SMA Negeri 1 Rantau Selatan, Kab. Labuhan Batu. Sampel penelitian diambil secara total sampling sebanyak 129 siswa. Instrumen penelitian adalah tes pilihan berganda dan angket. Hasil penelitian menunjukkan: (1) persentase tingkat kesulitan belajar siswa pada setiap aspek kognitif soal C1,C2,C3,C4,C5 dan C6 dan berturut-turut sebesar 43,05\%, 48,15\%,49,36\%, 50,17\% ,61,54\%, 69,93\%; (2) persentase kesulitan belajar setiap indikator soal pada materi virus meliputi: (1) indikator mengidentifikasi ciri-ciri virus sebesar 42,24\%, (2) indikator membedakan struktur tubuh virus dengan mahkluk lainnya sebesar 53,03\%, (3) indikator menjelaskan cara reproduksi virus 53,72\%, (4) indikator menjelaskan peranan virus bagi kehidupan sebesar 56,64\%, dan (5) indikator mengkomunikasikan cara menghindari diri dari bahaya virus seperti influenza, AIDS, flu burung dan lain-lain sebesar 50,7\%; dan (3) faktor yang, menghambat siswa dalam mempelajari materi tumbuhan virus adalah jasmaniah, psikologis, orangtua, guru biologi, pelajaran, lingkungan sekolah. Disimpulkan bahwa terdapat kesulitan belajar siswa pada materi virus di kelas $\mathrm{X}$ MIPA SMA Negeri 1 Rantau Selatan Tahun Pembelajaran 2017/2018.
\end{abstract}

Kata kunci : kesulitan belajar, aspek kognitif, dan faktor penyebab kesulitan belajar

\section{ABSTRACT}

This study aims to determine the level of learning difficulties students on Virus material in terms of cognitive aspects, learning indicators and factors causing. The method used is the analysis of the causes of students' learning difficulties. The research design is descriptive quantitative. Population in research is all students of class X IPA SMA Negeri 1 Rantau Selatan, Kab. Labuhan Batu. The sample was taken in total sampling as many as 129 students. The research instruments are multiple choice test and questionnaire. The results showed: (1) the percentage of students' learning difficulties on each cognitive aspect of C1, C2, C3, C4, C5 and C6 and 43.05\%, 48.15\%, 49.36\%, 50, 17\%, 61.54\%, 69.93\%; (2) indicator to differentiate body structure of virus with other creature equal to $53,03 \%,(3)$ indicator to identify virus characteristic by $42,24 \%,(2)$ explain the way of virus reproduction $53,72 \%$, (4) indicator explain the role of virus for life equal to $56,64 \%$, and (5) indicator communicate how to avoid self from danger of virus like influenza, AIDS, bird flu etc 50, 7\%; and (3) factors that, inhibiting students in studying viral plant matter are physical, psychological, parent, biology teacher, lesson, school environment. It was concluded that there were students' learning difficulties on virus material in class X MIPA SMA Negeri 1 Rantau Selatan Tahun Learning 2017/2018.

Keywords: learning difficulties, cognitive aspects, and factors causing learning difficulties

\section{PENDAHULUAN}

Belajar merupakan suatu proses perubahan yaitu perubahan tingkah laku sebagai hasil dari interaksi dengan lingkungannya dalam memenuhi kebutuhan hidupnya. Perubahanperubahan tersebut akan nyata dalam seluruh aspek tingkah laku. Menurut Djamarah (2013), belajar mengajar adalah suatu kegiatan yang bernilai edukatif. Nilai edukatif mewarnai interaksi yang terjadi antara guru dengan siswa. Interaksi yang bernilai edukatif dikarenakan kegiatan belajar mengajar yang dilakukan, diarahkan untuk mencapai tujuan tertentu yang telah dirumuskan sebelum pengajaran dilakukan seperti dalam Undang-undang nomor 20 Tahun 2003 tentang sistem pendidikan nasional.

Dalam kegiatan pembelajaran di sekolah, para pendidik dihadapkan dengan sejumlah 
karakteristik siswa yang beraneka ragam. Ada siswa yang dapat menempuh kegiatan belajarnya secara lancar dan berhasil tanpa mengalami kesulitan, namun disisi lain tidak sedikit pula siswa yang justru dalam belajarnya mengalami berbagai kesulitan.

Kesulitan belajar adalah suatu kondisi yang mana anak didik tidak belajar sebagaimana mestinya karena ada gangguan tertentu. Istilah kesulitan belajar yang penulis maksudkan ialah suatu kondisi di mana anak didik tidak dapat belajar secara maksimal disebabkan adanya hambatan, kendala atau gangguan dalam belajarnya. Ketika kesulitan belajar terjadi tentu hambatan hadir dalam kegiatan belajar mata pelajaran sehingga berakibat hasil belajarnya rendah (Dimyati, 2013).

Hal senada juga diungkapkan oleh Syah, 2011, kesulitan belajar menjadi suatu kendala terkemuka yang dialami siswa sekolah atau mahasiswa di perguruan tinggi. Fenomena kesulitan belajar seorang siswa biasanya tampak jelas dari menurunnya kinerja akademik atau prestasi belajarnya. Namun kesulitan belajar juga dapat dibuktikan dengan munculnya kelainan prilaku (misbehaviour) siswa. Siswa yang berprestasi belajar rendah biasanya mengalami kesulitan dimana aktivitas belajar bagi setiap siswa tidak selamanya berlangsung secara wajar, kadangkadang lancar, kadang-kadang teramat sulit, terkadang kurang konsentrasi dan masih banyak lagi kesulitan belajar yang dialami oleh siswa (Rusgiarti, 2011)

Virus merupakan salah satu materi yang terdapat dalam pembelajaran biologi. Materi ini ditujukan kepada siswa SMA kelas $X$ semester ganjil. Siswa diharapkan memperoleh pengetahuan mengenai ciri-ciri virus, struktur tubuh virus, cara replikasi virus, peranan virus yang menguntungkan maupun merugikan dalam kehidupan sehari-hari dan lingkungan siswa. Dalam Tsabari (2010), materi virus termasuk ke dalam topik mikrobiologi. Dalam topik mikrobiologi, termasuk di dalamnya virus, bakteri dan jamur. Ketiga materi ini banyak menggunakan bahasa dan istilah latin yang sulit dipahami siswa. Kebanyakan siswa sering salah membedakan virus dan bakteri, termasuk nama dan penyakit yang ditimbulkannya.

Simon (2017) menyatakan bahwa siswa sering menganggap virus adalah bakteri dan virus adalah sel prokariotik. Dikarenakan keduanya baik virus maupun bakteri banyak memakai bahasa latin dan memiliki struktur tubuh yang mirip sebagai mikroorganisme. Hal ini semakin menguatkan persepsi selama ini yang menyatakan bahwa letak kesulitan dalam pembelajaran materi - materi dalam biologi terletak pada kesulitan mengingat nama-nama latin, menghapal konsep-konsep dan membayangkan hal-hal yang abstrak.

Studi pendahuluan yang dilakukan dalam penelitian ini adalah wawancara dengan salah seorang guru pada sekolah SMA Negeri 1 Rantau Selatan. Menurut hasil studi tersebut, hasil belajar pada materi virus masih rendah. Hal ini diketahui dari nilai ulangan harian siswa pada materi virus berada dibawah Kriteria Ketuntasan Minimal (KKM) yang sudah ditetapkan oleh sekolah. Di SMA N 1 Rantau Selatan nilai KKM biologinya adalah 75.

Kesulitan belajar yang dihadapi siswa kelas $\mathrm{X}$ antara lain: (1) Materi Virus sulit dipahami siswa hal ini terlihat dari $65 \%$ hasil belajar biologi siswa masih rendah yakni nilai rata-rata masih dibawah KKM (Kriteria Ketuntasan Minimal) yang telah ditetapkan yaitu 75 karena banyak terdapat bahasa latin, (2) Rendahnya kemampuan siswa mengingat materi pelajaran yang telah diajarkan. Keadaan ini tentu akan menyebabkan siswa tidak mampu menyerap materi pelajaran dengan baik sehingga mengakibatkan rendahnya hasil belajar siswa, (3) Metode dan media yang digunakan saat mengajar materi virus belum memadai.

Berdasarkan hasil penelitian Umiyati (2014) mengenai faktor-faktor penyebab kesulitan belajar siswa kelas $\mathrm{X}$ pada mata pelajaran biologi materi virus menunjukkan bahwa terdapat faktor internal dan faktor eksternal yang mempengaruhi kesulitan belajar siswa. Faktor internal penyebab kesulitan belajar di antaranya pada aspek kesehatan, kelelahan, perhatian, minat dan kesiapan. Sedangkan faktor eksternal penyebab kesulitan belajar siswa diantaranya aspek suasana rumah, pengertian orang tua, teman bergaul di rumah, metode mengajar guru, interaksi guru dengan siswa, interaksi siswa dengan siswa, alat penunjang pembelajaran, materi pembelajaran dan kurikulum. Faktor internal yang paling mempengaruhi kesulitan belajar adalah faktor minat sedangakan faktor eksternal yang mempengaruhi kesulitan belajar siswa adalah aspek alat penunjang pembelajaran.

Untuk memahami beberapa besar tingkat kesulitan dan titik kesulitan siswa dalam belajar, maka dapat dilakukan dengan berbagai cara. Salah satunya adalah menganalisis hasil evaluasi belajar siswa. Gambaran tingkat kesulitan belajar akan dapat terlihat dari hasil evaluasi belajar mereka. 


\section{METODE PENELITIAN}

Penelitian ini dilaksanakan di SMA Negeri 1 Rantau Selatan yang beralamat di Jl. Ki Hadjar Dewantara, Kel. Sioldengan, Kec. Rantau Selatan, Kab. Labuhan Batu, Prov. Sumatera Utara. Waktu penelitian ini dilaksanakan pada bulan Oktober sampai Desember 2017. Populasi pada penelitian ini adalah seluruh siswa Kelas X MIA Tahun Pembelajaran 2017/2018 yang terdiri atas 4 kelas dengan jumlah siswa keseluruhan sebanyak 143 orang. Sampel dalam penelitian ini diambil secara total sampling (sampel total).

Instrumen penlitian ini yaitu angket. Jenis penelitian ini adalah deskriptif yang bersifat kuantitatif yaitu semua informasi atau data yang diwujudkan dalam bentuk kuantitatif atau angka dan analisanya berdasarkan angka tersebut dengan menggunakan analisis statistik. Tes yang diberikan bertujuab untuk mengukur kesulitan belajar siswa dalam mempelajari materi virus. Tes disusun berdasarkan tingkat kesukaran C1 (Pengetahuan), C2 (Pemahaman), C3 (Penerapan), C4 (Analisis), C5 (Evaluasi), C6 (Kreasi). Jumlah tes adalah 30 soal dalam bentuk pilihan berganda. Angket kesulitan belajar dibuat berdasarkan faktor internal dan faktor eksternal penyebab kesulitan belajar siswa . Faktor-faktor tersebut merupakan pendapat ahli dalam Slameto (2010). Dari faktor-faktor tersebut dibuat aspek-aspek yang perlu diamati untuk pembuatan angket. Tiap-tiap pertanyaan disediakan pilihan yang menjadi alternatif jawaban. Analisis data dalam penelitian ini menggunakan metode deskriptif kuantitatif. Secara deskriptif dimaksudkan untuk memberikan jawaban terhadaprumusan masalah yaitu mengenai kesulitan belajar siswa pada materi virus.

Dari hasil belajar siswa ditentukan ketuntasan belajar siswa secara individual dihitung dari jumlah skor diperoleh dibagi skor maksimal dikali $100 \%$ (Arikunto, 2013). Sebagai konsekuensi dari uraian diatas dapat disusun kriteria kesulitan pada siswa yang terdapat dalam tabel berikut: 0-20\% (Sangat Rendah), 21-40\% (Rendah), 41-60 (Sedang), 61-80 (Tinggi), 81-100 (Sangat Tinggi), (Zikra,2016).

\section{HASIL PENELITIAN}

Data hasil tes belajar siswa berdasarkan aspek kognitif diperoleh dari instrumen tes. Sebelumnya, siswa telah selesai mempelajari materi virus. Nilai rata-rata dari hasil tes belajar siswa pada materi virus di kelas X SMA Negeri 1 Rantau Selatan Tahun Pembelajaran 2017/2018 disajikan pada Tabel 1.

Tabel 1. Distribusi Kesulitan Belajar Siswa Pada Aspek Kognitif

\begin{tabular}{ccccccc}
\hline No & $\begin{array}{c}\text { Aspek } \\
\text { Kognitif }\end{array}$ & $\begin{array}{c}\text { Skor } \\
\text { Ideal }\end{array}$ & $\begin{array}{c}\text { Skor } \\
\text { Capaian }\end{array}$ & $\begin{array}{c}\text { Daya } \\
\text { Serap (\%) }\end{array}$ & $\begin{array}{c}\text { Kesulitan Belajar } \\
\text { Siswa (\%) }\end{array}$ & $\begin{array}{c}\text { Kategori Tingkat } \\
\text { Kesulitan }\end{array}$ \\
\hline 1 & C1 & 1287 & 733 & 56,95 & 43,05 & Sedang \\
2 & C2 & 1144 & 593 & 51,84 & 48,15 & Sedang \\
3 & C3 & 1001 & 507 & 50,65 & 49,36 & Sedang \\
4 & C4 & 572 & 285 & 49,83 & 50,17 & Sedang \\
5 & C5 & 143 & 55 & 38,46 & 61,54 & Tinggi \\
6 & C6 & 143 & 43 & 30,07 & 69,93 & Tinggi \\
\hline
\end{tabular}

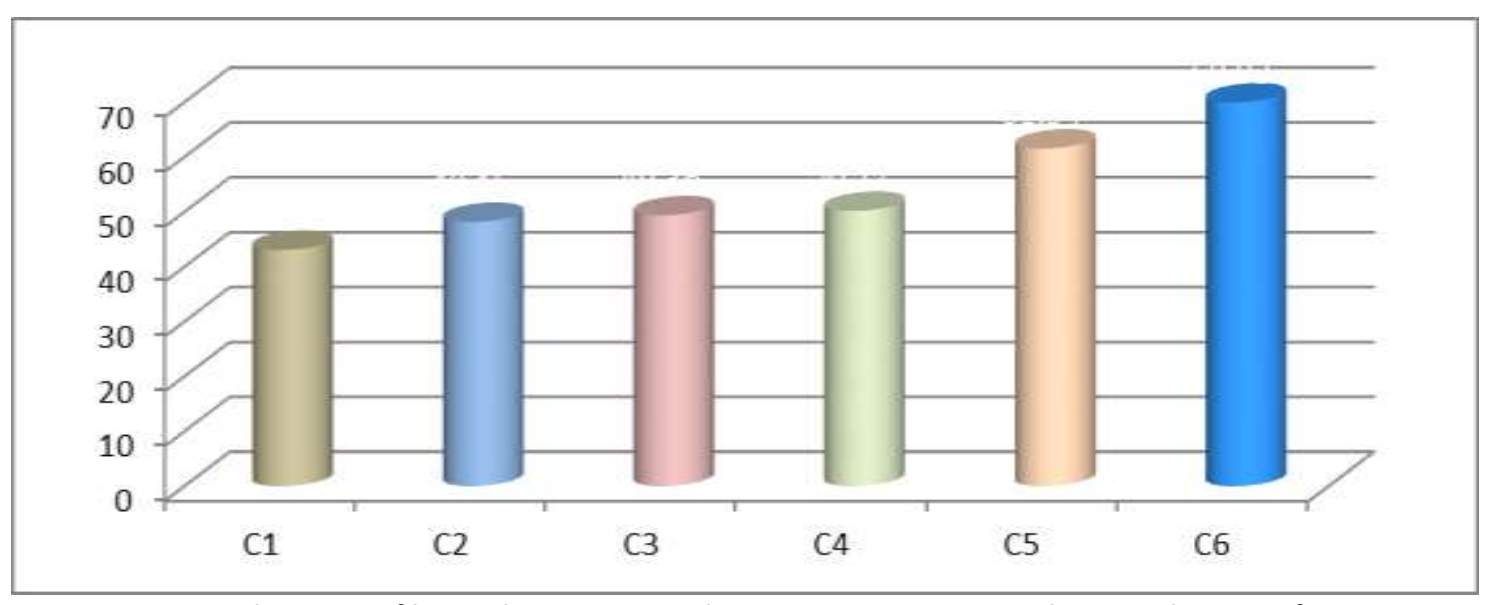

Gambar 1. Grafik Kesulitan Siswa Pada Materi Virus Ditinjau dari Aspek Kognitif 
Dari tabel 1 dan gambar diketahui bahwa persentase kesulitan belajar siswa pada tingkat pengetahuan (C1) yaitu sebesar $43,05 \%$ yang dikategorikan ke dalam tingkatan yang sedang, karena memiliki daya serap yang cukup, yaitu sebesar 56,95\%. Persentase kesulitan belajar pada tingkat Pemahaman (C2) yaitu sebesar $48,15 \%$. Persentase kesulitan belajar tersebut dikategorikan ke dalam tingkatan yang sedang, karena memiliki daya serap yang cukup 49,36\%. Persentase kesulitan belajar siswa pada tingkat Penerapan (C3), yaitu sebesar 50,65\%. Persentase kesulitan tersebut dikategorikan ke dalam tingkatan yang sedang, karena memiliki daya serap yang cukup yaitu $49,36 \%$. Persentase kesulitan belajar siswa pada tingkat analisis (C4) yaitu sebesar 50,17\%. Persentase kesulitan tersebut dikategorikan ke dalam tingkatan yang sedang karena memiliki daya serap yang cukup yaitu 49,83\%. Persentase kesulitan belajar siswa pada tingkat (C5) evaluasi yaitu sebesar 61,54\%. Persentase kesulitan tersebut dikategorikan ke dalam tingkatan yang tinggi karena memiliki daya serap yang sangat rendah yaitu sebesar $38,46 \%$. Persentase kesulitan belajar siswa pada tingkat kreasi (C6) yaitu sebesar $69,93 \%$. Persentase kesulitan belajar tersebut dikategorikan ke dalam tingkatan yang tinggi karena memiliki daya serap yang rendah yaitu sebesar 30,07\%.

Tabel 2. Distribusi Tingkat Kesulitan Belajar Siswa di Setiap Indikator Pembelajaran pada Materi Virus

\begin{tabular}{|c|c|c|c|c|c|c|}
\hline No. & Indikator Pembelajaran & $\begin{array}{l}\text { Skor } \\
\text { Ideal }\end{array}$ & $\begin{array}{c}\text { Skor } \\
\text { Capaian }\end{array}$ & $\begin{array}{l}\text { Daya } \\
\text { Serap } \\
(\%)\end{array}$ & $\begin{array}{l}\text { Kesulitan } \\
\text { Belajar } \\
\text { Siswa }\end{array}$ & $\begin{array}{l}\text { Kategori } \\
\text { Tingkat } \\
\text { Kesulitan }\end{array}$ \\
\hline 1 & Mengidentifikasi ciri-ciri virus & 1430 & 826 & 57,76 & 42,24 & Sedang \\
\hline 2 & $\begin{array}{l}\text { Membedakan struktur tubuh virus dengan } \\
\text { mahluk lain }\end{array}$ & 858 & 403 & 46,97 & 53,03 & Sedang \\
\hline 3 & Menjelaskan cara replikasi virus & 715 & 331 & 46,29 & 53,72 & Sedang \\
\hline 4 & $\begin{array}{l}\text { Menjelaskan peranan virus bagi } \\
\text { kehidupan }\end{array}$ & 715 & 310 & 43,36 & 56,64 & Tinggi \\
\hline 5 & $\begin{array}{l}\text { Mengkomunikasikan cara menghindari diri } \\
\text { dari bahaya virus seperti influenza, AIDS, } \\
\text { flu burung dan lain-lain. }\end{array}$ & 572 & 282 & 49,30 & 50,7 & Sedang \\
\hline
\end{tabular}

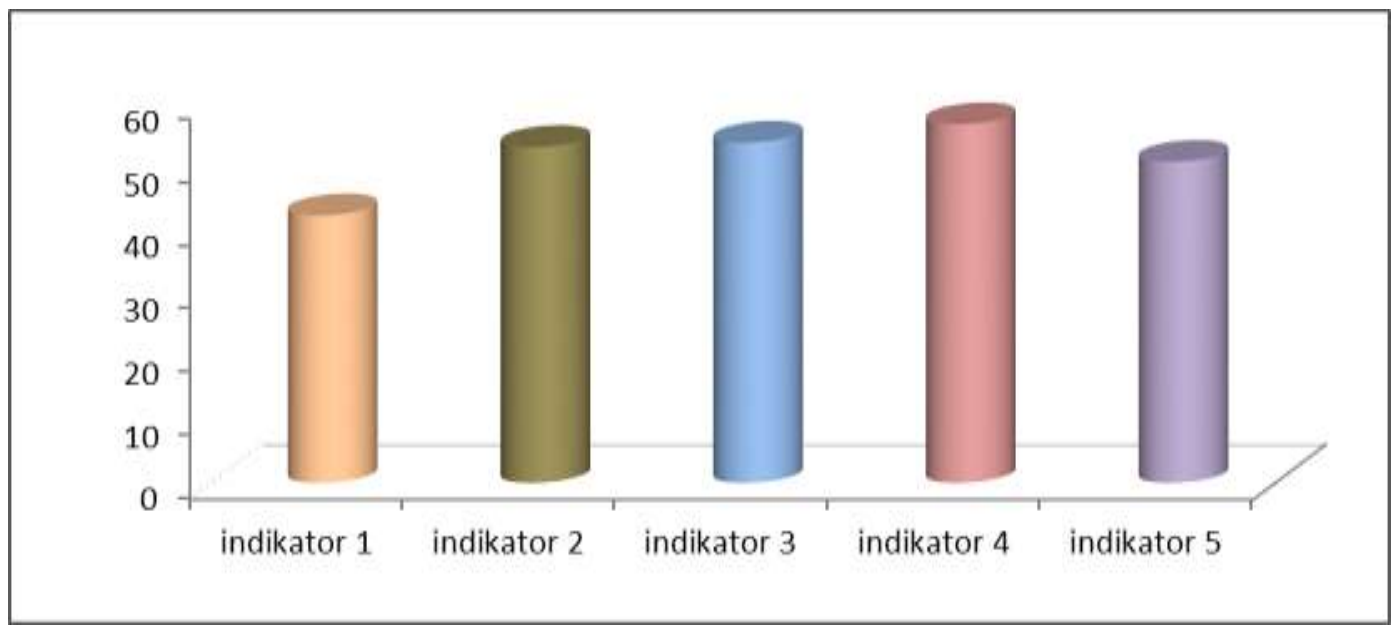

Gambar 2. Grafik Kesulitan Belajar Siswa Pada Materi Virus ditinjau dari Aspek Indikator Pembelajaran. Keterangan indikator: 1. mengidentifikasi ciri-ciri virus, 2. membedakan struktur tubuh virus dengan mahluk lain, 3. menjelaskan cara replikasi virus, 4. menjelaskan peranan virus bagi kehidupan, 5. mengkomunikasikan cara menghindari diri dari bahaya virus seperti influenza, AIDS, flu burung dan lain-lain. 
Dari Gambar 2 diperoleh daya serap siswa pada setiap aspek indikator sehingga diperoleh tingkat kesulitan belajar siswa pada indikator pembelajaran. Tingkat kesulitan belajar tertinggi terdapat pada indikator (4) menjelaskan peranan virus bagi kehidupan dengan persentase sebesar $56,64 \%$. Sedangkan tingkat kesulitan belajar terendah terdapat pada indikator (1) mengidentifikasi ciri-ciri virus dengan persentase kesulitan sebesar 42,24\%.

Data kesulitan belajar biologi berdasarkan faktor internal dan faktor eksternal siswa diperoleh dari angket. Angket yang digunakan bersifat tertutup. Jumlah angket yang dibagikan ke responden yaitu 30 . Untuk lebih jelasnya dapat dilihat pada diagram batang berikut.

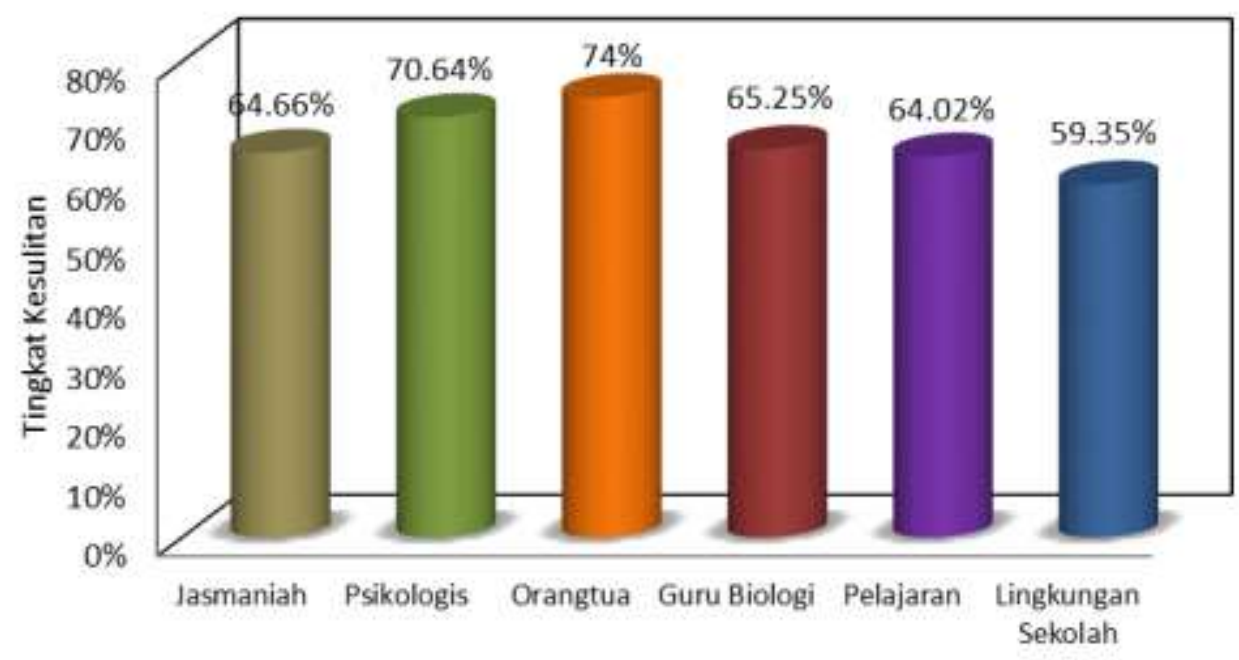

Gambar 3. Grafik Kesulitan Belajar Siswa Pada Materi Virus ditinjau dari Faktor Internal dan Faktor Eksternal

Dari Gambar 3 diperoleh hasil angket siswa dari setiap indikator faktor penyebab kesulitan belajar siswa. Indikator Jasmaniah menunjukkan persentase sebesar $64,66 \%$. Hal ini menunjukkan bahwa faktor jasmaniah dikategorikan berpengaruh terhadap kesulitan belajar siswa. Indikator Psikologis menunjukkan persentase sebesar 70,64\%. Kemudian, 3 faktor berikutnya yaitu orangtua sebesar $74 \%$, faktor guru Biologi sebesar 62,25\%, dan faktor pelajaran sebesar 64,02\% menunjukkan bahwa ketiga faktor tersebut berpengaruh terhadap kesulitan belajar siswa. Dan, faktor terakhir yaitu lingkungan sekolah menunjukkan persentase sebesar 59,35\% dengan kategori cukup berpengaruh terhadap kesulitan belajar siswa. Dari ke-enam faktor tersebut yang meliputi faktor jasmaniah,psikologis, orangtua, guru biologi, pelajaran dan lingkungan sekolah, kesemua faktor berpengaruh pada kesulitan belajar siswa pada materi virus.

\section{PEMBAHASAN}

\section{Kesulitan Belajar Siswa Dari Hasil Tes}

Dari hasil penelitian pada aspek pengetahuan/mengingat (C1) tingkat kesulitan siswa termasuk ke dalam kategori sedang karena rata-rata daya serap siswa sebesar 56,95\%. Ini menunjukkan bahwa kesulitan yang dialami siswa kelas X MIA SMA Negeri 1 Rantau Selatan pada aspek kognitif di tingkat Pengetahuan/Mengingat (C1) termasuk kategori sedang artinya dalam menyelesaikan soal dengan kategori C1, siswa masih mengalami kesulitan tetapi masih dalam level yang rendah.

Pada aspek pemahaman (C2), tingkat kesulitan siswa termasuk ke dalam kategori sedang karena daya serap siswa 51,84\%. Ini menunjukkan bahwa kesulitan yang dialami siswa kelas X MIA SMA Negeri 1 Rantau Selatan pada aspek kognitif di level pemahaman (C2) masih dalam kategori sedang, artinya dalam menyelesaikan soal kategori C2 , siswa mengalami kesulitan tetapi masih dalam level yang sedang. Berdasarkan hasil penelitian yang dilakukan oleh Husnifa dan Ely (2012) bahwa persentase kesulitan belajar siswa pada level C2 sebesar 31,58\%. Aspek kognitif C2 memiliki tingkat kesulitan belajar yang lebih tinggi dibandingkan dengan tingkat kesulitan pada aspek kognitif C1, karena pada aspek kognitif C2 siswa dituntut untuk dapat memahami dan menyimpulkan apa yang telah dipelajari pada materi virus. Untuk menjawab soal tingkat C2 siswa perlu memahami 
dan menyimpulkan materi pelajaran virus yang telah diajarkan sebelumnya oleh guru, seperti komponen penyusun tubuh virus yang termasuk ke dalam ciri-ciri virus dan penyakit yang diakibatkan oleh virus. Hal ini biasa terjadi karena siswa tidak mengingat (lupa) apa yang telah diajarkan oleh guru biologi tentang materi virus.

Pada aspek kognitif C3 (aplikasi), tingkat kesulitan belajar siswa kelas X IPA SMA Negeri 1 Rantau Selatan tergolong sedang, dengan persentase siswa yang mengalami kesulitan belajar sebesar 49,36\%, sementara siswa yang mampu mencapai keberhasilan belajar pada aspek ini adalah sebesar $50,65 \%$. Berdasarkan hasil analisis jawaban siswa pada soal tingkatan C-3 diperoleh bahwa banyak siswa dapat mengurutkan proses replikasi virus secara runut dan benar, menerapkan teori ketika virus berada di dalam tubuh dan mengetahui cara sederhana untuk mencegah penularan virus. Akan tetapi masih banyak siswa yang belum mengetahui pencegahan terhadap infeksi virus melalui vaksin, cara pengunaan vaksin dan jenis-jenis vaksin. Hal tersebut bisa terjadi dikarenakan masih banyak siswa yang kurang aktif dalam mencari penjelasan tambahan yang berkaitan dengan materi virus.

Pada aspek kognitif C4, tingkat kesulitan belajar siswa kelas X IPA SMA Negeri 1 Rantau Selatan tergolong sangat tinggi, dengan persentase siswa yang mengalami kesulitan belajar sebesar $50,17 \%$, sementara siswa yang mampu mencapai keberhasilan belajar pada aspek ini adalah sebesar 49,83\%. Pada tingkat kognitif ini masih banyak siswa yang belum mampu menganalisis materi virus, terutama dalam menganalisis efek dari infeksi virus bersiklus litik pada tubuh manusia dan menganalisis ciri-ciri virus berdasarkan cara hidupnya. Siswa juga belum mampu menganalisis keterkaitan antara nama virus dan penyakit yang ditimbulkannya. Hal tersebut bisa terjadi karena siswa tidak menambah pengetahuannya dengan membaca sumber-sumber lain tentang virus selain buku pelajaran.

Pada aspek kognitif C5, tingkat kesulitan belajar siswa kelas X IPA SMA Negeri 1 Rantau Selatan tergolong sangat tinggi, dengan persentase siswa yang mengalami kesulitan belajar sebesar $61,54 \%$, sementara siswa yang mampu mencapai keberhasilan belajar pada aspek ini adalah sebesar $38,46 \%$. Pada aspek ini siswa dituntut untuk menentukan kombinasi yang benar antara kelompok virus dan karakteristiknya,siswa sulit menyimpulkan replikasi virus secara tepat, dan siswa belum mampu menyimpulkan proses masuknya virus ke dalam tubuh inang. Hal ini bisa terjadi karena siswa belum memahami konsep materi virus dan peristiwa-peristiwa yang terjadi selama proses replikasi virus berlangsung.

Pada aspek kognitif C6, tingkat kesulitan belajar siswa kelas X IPA SMA Negeri 1 Rantau Selatan tergolong sangat tinggi, dengan persentase siswa yang mengalami kesulitan belajar sebesar $69,93 \%$, sementara siswa yang mampu mencapai keberhasilan belajar pada aspek ini adalah sebesar 30,07\%. Aspek kognitif C6 memiliki tingkat kesulitan belajar yang paling tinggi dibandingkan dengan kesulitan pada aspek kognitif C5,C4,C3,C2 dan $\mathrm{C} 1$.

Pada kategori C6, siswa mengalami kesulitan di soal tentang membuat medium yang tepat untuk jenis virus yang sesuai. Hal ini dikarenakan siswa tidak mengingat ciri-ciri virus sebagai mahkluk hidup. Siswa belum menguasai konsep bahwa virus hanya bisa hidup pada sel hidup, sehingga siswa menganggap virus juga dapat di hidup di medium biakan yang bukan termasuk sel hidup. Berdasarkan pernyataan tersebut maka dapat disimpulkan bahwa tingginya tingkat kesulitan belajar siswa kelas X MIA SMA Negeri 1 Rantau Selatan pada aspek kognitif terjadi karena soal materi virus yang disusun dalam aspek kognitif C6 memiliki tingkat kesukaran yang lebih tinggi dibandingkan dengan tingkatan aspek kognitif lainnya. Pada kategori C6, siswa mengalami kesulitan di soal mengenai medium yang tepat sebagai biakan untuk virus. Hal ini dikarenakan medium biakan untuk virus dan medium biakan untuk bakteri hampir sama.

\section{Faktor Penyebab Kesulitan Belajar Siswa}

Berdasarkan analisis terhadap faktor
kesulitan belajar siswa, di peroleh bahwa
persentase faktor jasmaniah adalah sebesar
$64,66 \%$ yang termasuk dalam kategori
berpengaruh terhadap kesulitan belajar. Hasil
penelitian ini menunjukkan bahwa sebagian besar
siswa mengalami kesulitan dalam belajar yang
dipengaruhi oleh faktor jasmaninya. Faktor
jasmaniah terdiri dari dua indikator yaitu
kesehatan dan cacat tubuh. Berdasarkan
penelitian yang dilakukan Ristiyani E., dan Bahriah,
E.S. (2016) menunjukkan bahwa faktor
jasmani/panca indera mencapai 74,5\% dengan
kategori tinggi. Kesehatan jasmani sangat besar
pengaruhnya terhadap kemampuan belajar. Bila
seseorang selalu tidak sehat, sakit kepala,
demam,pilek,batuk dan sebagainya, dapat


mengakibatkan tidak bergairah untuk belajar (Dalyono, 2015)

Faktor psikologis terdiri dari intelegensi, minat dan motivasi. Faktor psikologi memiliki persentase sebesar 70,64\% yang termasuk ke dalam kategori berpengaruh terhadap kesulitan belajar siswa. Hasil penelitian ini menunjukkan bahwa sebagian besar siswa Kelas X IPA SMA Negeri 1 Rantau Selatan mengalami kesulitan dalam belajar yang dipengaruhi oleh faktor psikologisnya. Berdasarkan hasil penelitian yang dilakukan oleh Zikra (2016) faktor psikologis memiliki persentase sebesar $71 \%$ yang termasuk ke dalam kategori tinggi. Seseorang yang memiliki intelegensi yang baik, umumnya mudah belajar dan hasilnya pun cenderung baik. Sebaliknya orang yang intelegensinya rendah, cenderung mengalami kesukaran dalam belajar, lambat berpikir sehingga prestasi belajarnya pun rendah (Dalyono, 2015). Kecerdasan siswa sangat membantu pengajar untuk menentukan apakah siswa itu mampu mengikuti pelajaran yang diberikan (Mardianto, 2014).

Faktor eksternal terdiri dari orangtua, guru biologi, pelajaran dan lingkungan sekolah. Faktor orangtua menunjukkan persentase sebesar 74\% dan termasuk dalam kategori berpengaruh terhadap kesulitan belajar siswa. Hasil penelitian ini menunjukkan bahwa sebagian besar siswa SMA Negeri 1 Rantau Selatan mengalami kesulitan dalam belajar dipengaruhi faktor orangtua. Faktor orang tua sangat besar pengaruhnya terhadap keberhasilan anak dalam belajar. Menurut Hamalik (2005), orangtua turut bertanggungjawab atas kemajuan studi anaknya. Anak belajar perlu dorongan dan pengertian orang tua. Kadangkadang anak mengalami lemah semangat orang tua wajib memberi pengertian dan mendorongnya membantu sedapat mungkin kesulitan yang dialami anak di sekolah (Slameto, 2013).

Faktor guru memiliki persentase sebesar $65,25 \%$ dan termasuk kategori berpengaruh terhadap kesultan belajar siswa. Hasil penelitian ini menunjukkan bahwa hampir setengah siswa SMA Negeri 1 Rantau Selatan mengalami kesulitan dalam belajar dipengaruhi oleh faktor guru. Untuk faktor guru terdapat beberapa indikator yaitu metode guru dalam mengajar, media, relasi guru dengan siswa,disiplin sekolah dan standar pelajaran. Dari hasil angket lebih banyak siswa yang menjawab tidak pernah untuk pernyataan guru menggunakan media animasi dan alat peraga saat belajar materi virus sehingga siswa sulit memahami

materi

virus.

Faktor pelajaran memiliki persentase sebesar 64,02\% dan termasuk dalam kategori berpengaruh terhadap kesulitan belajar siswa. Hasil penelitian ini menunjukkan sebagian besar siswa kelas X MIPA SMA Negeri 1 Rantau Selatan mengalami kesulitan dalam belajar dipengaruhi oleh faktor pelajaran. Hal ini sejalan dengan penelitian Umiyati dan Susilo (2014) bahwa materi pelajaran menjadi faktor tertinggi yang menyebabkan kesulitan belajar. Rata-rata peserta didik menganggap materi virus tidak menarik, sehingga minat peserta didik untuk belajar berkurang. Menurut penelitian Purwati, N., dkk (2015), terdapat sebesar 50\% siswa dari beberapa sekolah mengaku sulit mempelajari materi virus karena materi ini tergolong materi yang sulit dan abstrak dan sebesar $56,67 \%$ siswa tidak tahu bagaimana cara mengaplikasikan konsep virus ke dalam kehidupan nyata. Penelitian yang dilakukan oleh Tim, A., dan Oyovwi, E., (2015) terdapat 7 alasan siswa menganggap topik dalam biologi itu sulit, salah satunya adalah sifanya yang abstrak dan membutuhkan banyak berpikir. Oleh karena itu, dalam pembelajarannya, materi virus membutuhkan visual yang baik yang dapat menampilkan kenampakan bentuk aslinya sehingga kesulitan siswa dapat terkurangi (Ikhsaniyah,2015).

Faktor Lingkungan Sekolah memiliki persentase sebesar 59,35\% dan termasuk ke dalam kategori cukup berpengaruh. Hasil penelitian ini menunjukkan bahwa hanya sebagian kecil siswa kelas X MIPA SMA Negeri 1 Rantau Selatan yang mengalami kesulitan dalam belajar dipengaruhi oleh faktor lingkungan sekolah. Untuk faktor lingkungan sekolah terdiri dari keadaan kelas dan fasilitas sekolah. Faktor ini memiliki persentase terendah sehingga dapat dikategorikan kurang mempengaruhi kesulitan belajar siswa. Keadaan kelas di SMA Negeri 1 Rantau Selatan terbilang memadai, dengan pencahayaan yang cukup yang berasal dari jendela dan lampu.

Menurut penelitian Husnifa dan Ely (2016), faktor eksternal yang peling mempengaruhi kesulitan belajar siswa kelas $\mathrm{X}$ pada materi virus adalah faktor alat penunjang pembelajaran yang kurang memadai (belum adanya laboratorium biologi, kurangnya kamus biologi, serta buku biologi yang tidak lengkap). Di SMA Negeri 1 Rantau Selatan memang terdapat laboratorium biologi, tetapi tidak dioptimalkan penggunaannya dan keadaan laboratorium dengan alat-alat yang 
kurang engkap membuat siswa kurang antusias jika harus memasuki laboratorium. Hasil jawaban siswa yang terdapat pada angket juga menunjukkan bahwa mereka tidak memiliki sumber buku lain selain buku pelajaran yang disediakan oleh sekolah. Hal ini menandakan bahwa siswa tidak memiliki sumber referensi lain seperti kamus biologi, dan lain-lain. Ristiyani E., dan Bahriah, S. (2016) menyatakan bahwa kesulitan untuk mendapatkan atau memiliki alat-alat pelajaran secara langsung maupun tidak langsung dapat mempengaruhi keberhasilan dalam belajar siswa.

\section{KESIMPULAN}

Persentase tingkat kesulitan belajar siswa pada setiap aspek kognitif soal C1,C2,C3,C4,C5 dan C6 dan berturut-turut sebesar $43,05 \%, 48,15 \%$, 49,36\%, 50,17\% ,61,54\%, 69,93\%; (2) persentase kesulitan belajar setiap indikator soal pada materi virus meliputi: (1) indikator mengidentifikasi ciriciri virus sebesar 42,24\%, (2) indikator membedakan struktur tubuh virus dengan mahkluk lainnya sebesar 53,03\%, (3) indikator menjelaskan cara reproduksi virus $53,72 \%$, (4) indikator menjelaskan peranan virus bagi kehidupan sebesar $56,64 \%$, dan (5) indikator mengkomunikasikan cara menghindari diri dari bahaya virus seperti influenza, AIDS, flu burung dan lain-lain sebesar 50,7\%; dan (3) faktor yang, menghambat siswa dalam mempelajari materi tumbuhan virus adalah jasmaniah, psikologis, orangtua, guru biologi, pelajaran, lingkungan sekolah.

\section{UCAPAN TERIMA KASIH}

Penulis mengucapkan terima kasih kepada Ibu Nora Novalina, S.Si., selaku guru pamong saya yang telah banyak membantu dan memberikan arahan dalam penyelesaian penelitian saya ini. Teman-teman khususnya buat sahabat biologi ekstensi B 2013 yang banyak memberikan kesan yang luar biasa kepada penulis.

\section{DAFTAR PUSTAKA}

Arikunto, S. (2013), Prosedur Penelitian:Suatu Pendekatan Praktik, Rineka Cipta, Jakarta.

Dalyono, M., (2015), Psikologi Pendidikan, Rineka Cipta, Jakarta.

Djamarah, B.S., Zain, A., (2013), Strategi Belajar Mengajar, Rineka Cipta, Jakarta.

Dimyati., Mudjiono., (2009), Belajar dan Pembelajaran, Rineka Cipta, Jakarta.
Hamalik, O., (2005), Metoda Belajar dan KesulitanKesulitan Belajar Edisi II, Tarsito, Bandung.

Ikhsaniyah, W., Efektivitas Media Komik Biologi Materi Virus Melalui Pembelajaran Kooperatif Tipe Cooperative Integrated Reading And Composition (CIRC) Terhadap Motivasi Dan Hasil Belajar Biologi Siswa Kelas X SMA Negeri 1 Sewon, Skripsi, FMIPA, UIN Sunan Kalijaga, Yogyakarta

Mardianto. (2014), Psikologi Pendidikan Landasan Untuk Pengembangan Strategi Pembelajaran. Perdana Publishing, Medan

Ristiyani, E., Bahriah, E.,S., (2016), Analisis Kesulitan Belajar Kimia Siswa Di SMAN X Kota Tangerang Selatan, Jurnal Penelitian dan Pembelajaran IPA, 2 (1):18-29

Slameto, (2013), Belajar Dan Faktor-Faktor Yang Mempengaruhinya Edisi Revisi Cetakan Keenam, Rineka Cipta, Jakarta.

Syah, M, (2011), Psikologi Belajar, Rajawali Pers, Jakarta.

Simon, U.K., Enzinger, S.M., Fink, A., (2017), "The evil virus cell": Student's knowledge and beliefs about viruses, Journal PLOS ONE, 12(3): 1-21

Tim, A., dan Oyovwi, E., (2015), Evaluating Effect of Student's Academic Achievement on Identified Difficult Concepts in Senior Secondary High School Biology in Delta State, Journal of Education and Practice, 6 (30) : 117-125

Tsabari, et al, (2010), Identifying Student's Interests in Biology Using Using a Decade of Self-Generated Questions, Eurasia Journal of Mathematics, 6 (1): 63-75

Umiyati, D., dan Susilo, M., J., (2014), Perbandingan Faktor-Faktor Penyebab Kesulitan Belajar antara Siswa Kelas X6 dengan Kelas X7 pada Mata Pelajaran Biologi Materi Virus, JUPEMASI-PBIO, 1 (1): 106-108.

Zikra, (2016), Analisis Faktor-faktor Penyebab Kesulitan Belajar Biologi Siswa Kelas Vii Mtss Pgai Padang, Jurnal BioCONCETTA, $2(2): 93-102$ 